\title{
РОЗДІЛ «ОСВІТА»
}

DOI 10.31319/2519-2884.32.2018.184

ДЕРЕЦЬ Є.В., к.ф.-м.н., доцент

Дніпровський державний технічний університет, м. Кам'янське

\section{ВИКОРИСТАННЯ КОМП'ЮТЕРНИХ ТЕХНОЛОГІЙ ПРИ НАВЧАННІ МАТЕМАТИКИ СТУДЕНТІВ СКОРОЧЕНОГО ТЕРМІНУ ПІДГОТОВКИ}

\begin{abstract}
Вступ. Згідно з Законом України „Про Основні засади розвитку інформаційного суспільства в Україні на 2007-2015 роки” одним із пріоритетних напрямів державної політики $є$ «створення системи освіти, орієнтованої на використання новітніх інформаційно-комунікаційних технологій у формуванні всебічно розвиненої особистості». За влучним виразом О.В.Співаковського, жоден технічний засіб, який застосовувався до цього часу, за своїми дидактичними можливостями використання не може зрівнятися 3 комп'ютером [1].

Проблеми використання комп'ютерних технологій, створення і впровадження комп'ютерно-орієнтованих методичних систем у навчанні математики, інформатики, фізики у середніх і вищих навчальних закладах досліджувались у працях багатьох науковців. У працях С.І.Машбиця, С.Д.Максименка, Б.С.Гершунського розглядались психолого-педагогічні основи застосування IКТ у навчанні. У працях Р.І.Клочка досліджувались нові інформаційні технології навчання математики в технічній вищій школі. С.А.Раков розглядав використання IКТ з точки зору компетентнісного підходу. Проблемам використання сучасних ІКТ у навчальному процесі присвячено багато робіт М.І.Жалдака, В.Ю.Бикова, Н.В.Морзе, Ю.С.Рамського, Ю.В.Триуса, .В.Співаковського та ін.

Комп'ютерно-орієнтовану методичну систему навчання (КОМСН) Ю.В.Триус визначає як методичну систему навчання, використання якої забезпечує цілеспрямований процес здобування знань, набуття умінь і навичок, засвоєння способів пізнавальної діяльності суб' єктом навчання і розвиток його творчих здібностей на основі широкого використання інформаційно-комунікаційних технологій [2]. На сьогодні існує багато напрацювань, присвячених дослідженню педагогічних особливостей створення і впровадження в навчальний процес КОМСН, разом з тим проблема дослідження методики навчання вищої та прикладної математики з використанням сучасних інформаційнокомунікаційних технологій лишається актуальною. Як справедливо відзначають Н.В.Морзе та О.Г.Глазунова, так само динамічно, як інформаційні технології, має розвиватися і методика їх використання у навчальному процесі, при цьому ефективності навчального процесу сприяє використання моделі інтеграції денної форми навчання 3 інформаційно-комунікаційними та дистанційними технологіями навчання [3].
\end{abstract}

Постановка задачі. Однією з проблем, що потребує подальшого педагогічного дослідження, є дослідження методики використання інформаційно-комунікаційних технологій при навчанні курсу вищої математики студентів скороченого терміну навчання. Особливості навчання математики студентів технічних спеціальностей скороченого терміну навчання полягають, на нашу думку, у тому, що, з одного боку, для них окремі поняття і факти курсу вищої математики повинні бути вже знайомими, однак разом 3 тим наявність тих чи інших тем курсу вищої математики у програмі ВНЗ I-II рівня акредитації не означає автоматично, що в той час, коли вивчення університетського курсу потребує відповідних компетентностей, залишкових знань виявиться достатньо. Крім того, рівень базової математичної підготовки у різних студентів однієї і тієї ж академічної групи може істотно відрізнятися. Таким чином виникає потреба стисло систематизувати знання, набуті при навчанні у технікумі, допомогти студентам ліквідувати наявні прогалини у математичній підготовці, створити умови для подальшого підвищення мотивації до навчання шляхом побудови математичних моделей професійно орієнтова- 
них задач. Одним із потужних засобів у вирішенні цієї проблеми є використання інформаційно-комунікаційних технологій. Метою статті є визначення методичних особливостей використання комп'ютерних технологій при навчанні вищої та прикладної математики студентів технічних спеціальностей, які навчаються за скороченим терміном підготовки бакалаврів.

Результати роботи. Вища та прикладна математика відноситься до дисциплін природничого циклу, які не можна перезарахувати автоматично при навчанні за скороченим терміном, оскільки обсяг цих дисциплін у ВНЗ I-II рівнів акредитації складає менше, ніж 40\% від університетської програми. Звичайно, важливим питанням $є$ узгодження робочих програм [4], але у нашому дослідженні основну увагу зосереджено на особливостях використання комп'ютерних технологій в процесі навчання математики студентів скороченого терміну.

Перш за все відзначимо, що на сучасному етапі розвитку науково-технічного прогресу виникає потреба у постійному вдосконаленні та інтенсифікації процесу підготовки інженерів у вищих навчальних закладах. В умовах значного скорочення часу на аудиторне вивчення дисциплін обсяг інформації, якою повинен оволодіти майбутній фахівець, постійно збільшується. Ю.В.Триус визначає „інформаційний бум” як одну з причин протиріч, що формуються і розвиваються в процесі змін вищої математичної освіти [2]. Для студентів скороченого терміну навчання проблема інформаційної перенасиченості постає особливо гостро. Одним із можливих шляхів розв'язання цієї проблеми є впровадження в навчальний процес інформаційно-комунікаційних технологій. Для студентів денної форми навчання (як повного, так і скороченого терміну) найбільш перспективним на думку багатьох дослідників є використання технологій змішаного або комбінованого навчання (,,blended learning”). Зарубіжна педагогічна література визначає термін „,blended learning” як таку технологію, яка поєднує в собі традиційне аудиторне навчання „face-to-face” з більш комп'ютерно-опосередкованою діяльністю [57]. За Ю.В.Триусом, комбіноване навчання - це ,цілеспрямований процес здобування знань, набуття умінь і навичок, засвоєння способів пізнавальної діяльності суб'єктами навчання та розвитку його творчих здібностей на основі комплексного і систематичного використання традиційних, інноваційних педагогічних технологій та інформаційнокомунікаційних технологій навчання за принципами взаємного доповнення з метою підвищення якості освіти" [8].

Для студентів скороченого терміну навчання пропонується створення і впровадження в навчальний процес стислих опорних електронних конспектів з базових розділів вищої математики, зокрема, у формі презентацій. Електронні конспекти повинні містити як матеріал, що є спільним у робочих програмах навчальних закладів різних рівнів, так і подальший його розвиток згідно з університетською програмою. Перший досвід опрацювання таких конспектів студенти повинні отримувати на початку семестру під час аудиторних лекційних занять, далі ж акцент поступово зміщується на самостійну роботу, для чого до електронних методичних матеріалів внесено також приклади розв'язання типових завдань та приклади тестових завдань для поточного контролю. При самостійному опрацюванні презентації студенти мають змогу перевірити рівень засвоєння матеріалу, самостійно даючи відповіді на наведені в мультимедійному продукті питання, при цьому правильна відповідь чи пояснення відкриваються тільки після додаткової команди. Якість опрацювання кожної теми систематично перевіряється експрес-тестуванням на наступних заняттях. При цьому частина завдань для самостійної роботи може бути варіативною і визначатися для кожного студента в залежності від результатів поточного контролю або результатів виконання індивідуальних завдань. Електронні методичні матеріали розподілені на порівняно невеликі тематичні блоки i містять автоматичні гіперпосилання на довідниковий матеріал з елементарної математики або відповідні пункти інших методичних матеріалів, таким чином, вдається запобігти виникненню психологічного бар'єру, коли навіть за наявності добре оснащеного і повного електронного методичного забезпечення значна частина студентів зі слабким i 
середнім рівнем підготовки уникає користуватися електронним порталом, оскільки вони переконані у тому, що обсяг інформації занадто великий і його опрацювання потребує надмірних зусиль.

Особливої уваги заслуговує використання комп’ютерних технологій під час підготовки студентів до практичних занять. При опрацюванні традиційних методичних матеріалів студент бачить вказівку до задачі або весь текст розв'язання в цілому, і при цьому у випадку, коли всі етапи розв'язання є зрозумілими, може виникати ілюзія повного оволодіння навчальним матеріалом, тоді як насправді при самостійному розв'язанні задач результати значно гірші. Використання інформаційних технологій може перевести самостійну роботу студента на якісно новий рівень, коли етапи розв'язання виникають на екрані поступово, текст пояснень може бути пов'язаний з вибором відповідей на поставлені питання, а отже, з помилками чи труднощами, що виникають у конкретного студента. Крім того, студенти мають змогу самостійно повторити хід розв'язання, звіряючись 3 електронним посібником на кожному кроці окремо. Відзначимо, що проведене нами анкетування серед студентів першого курсу повного та скороченого терміну навчання виявило, що серед студентів скороченої форми навчання помітно більший відсоток тих, хто віддає перевагу саме таким чином побудованому електронному методичному забезпеченню. На жаль, поширеною серед студентів $є$ також думка, що для професійних потреб цілком достатньо вже отриманих математичних компетентностей, тому для того, щоб переконати студентів у потужних прикладних можливостях математики, при підготовці електронного методичного забезпечення особливу увагу потрібно приділити практичній частині курсу, а саме - задачам професійного спрямування, пов'язаним з іншими дисциплінами.

Щодо контролю знань, ми поділяємо думку багатьох дослідників щодо того, що при вивченні курсу вищої та прикладної математики неможливо обмежитись лише комп'ютерним тестуванням, потрібне гармонічне поєднання тестових завдань 3 комп'ютерною перевіркою відповідей з завданнями відкритого типу, які перевіряє викладач. На нашу думку, корисно, коли студенти за допомогою Інтернету систематично мають можливість потренуватися у проходженні комп'ютерних тестів он-лайн у анонімному режимі після самостійного опрацювання лекційного матеріалу. При цьому студенти не зацікавлені у підробці результатів, позбавлені додаткового стресу, мають змогу реально оцінити якість своєї підготовки до майбутнього контролю, а у викладача накопичується статистика результатів, яка дозволяє вдосконалювати тести після статистичної обробки одержаних даних. Найкращі результати будуть досягнуті у тому випадку, коли студенти, по-перше, матимуть змогу висловити свою думку щодо запропонованих матеріалів та тестів, і ця думка буде враховуватися викладачем у подальшому, по-друге, викладач постійно та систематично буде проводити поточний контроль знань студентів, таким чином, регулярне опрацювання дидактичних матеріалів з використанням ІКТ стає обов'язковою умовою для досягнення високої рейтингової позиції. Крім того, зручним є оцінювання результатів кожного етапу проміжного контролю за 100 бальною шкалою, а не за балами, які згідно з робочою програмою відповідають конкретній темі, оскільки якість та динаміка власних досягнень стають для студентів більш зрозумілими та наочними. При остаточному підрахунку балів кожен показник 3 конкретної теми помножується на відповідний ваговий коефіцієнт таким чином, щоб отримати необхідне значення максимально можливих балів. Позитивний вплив на мотивацію до навчання може зробити автоматичне графічне зображення динаміки результатів конкретного студента, а також складання рейтингових таблиць проміжних результатів академічної групи.

Комп’ютерні технології, пов'язані з використанням математичних пакетів, дозволяють також створити ситуації, в яких студенти можуть відчути себе дослідниками. Наприклад, вже на початку вивчення курсу можна запропонувати побудувати за допомогою комп'ютерних засобів декілька еліпсів з різним значенням ексцентриситету і наочно впевнитися, як пов'язане значення ексцентриситету з формою кривої. При ви- 
вченні дослідження функцій корисною є попередня побудова декількох графіків за допомогою математичних пакетів 3 метою експериментального виявлення певних загальних закономірностей. По мірі вивчення курсу такі завдання можуть ставати більш складними і творчими. Математичні пакети доцільно також застосовувати для самоперевірки, а також для автоматизації тих обчислень, які при вивченні конкретної теми $\epsilon$ несуттєвими і лише відбирають час.

Разам з тим не можна не відзначити, що окрім беззаперечних переваг використання ІКТ мають місце також певні недоліки, пов'язані з використанням інформаційних технологій у навчальному процесі. Перш за все, це значні витрати часу викладача. В роботі [9] наводяться дані дослідження трудомісткості роботи викладача при традиційних методах навчання і при використанні ІКТ, при цьому отримані результати дозволяють автору зробити висновок, що в середньому традиційна методика та методика навчання $з$ використанням комп'ютерних засобів потребують приблизно однакових затрат часу викладача. Зазначимо, що при цьому мова вочевидь йде про вже усталені напрацювання, оскільки згідно з наведеними даними час на підготовку тесту при використанні ІКТ не витрачається. На нашу думку, при накопиченому досвіді і розроблених електронних методичних матеріалах витрати часу при використанні IКТ навіть зменшуються у порівнянні з традиційними методами, оскільки внесення коректив і доповнення існуючих розробок не потребує багато зусиль, але на початковому етапі навантаження на викладача є значним. Другим важливим фактором, який можна вважати недоліком, $\epsilon$ те, що використання студентами електронних засобів під час самостійної роботи потребує високого рівня самоконтролю, адже, знаходячись за комп'ютером, дуже легко перейти від навчання до розваг, а комп'ютерні технології використовувати лише під час іспитів як могутню шпаргалку. Таким чином, використання IКТ у навчальному процесі потребує особливої уваги до систематичного поточного контролю. Крім того, при впровадженні комп'ютерних технологій викладачеві потрібно слідкувати за тим, щоб сумарне навантаження на студентів, які сумлінно опрацьовують весь навчальний матеріал, не виявилось надмірним.

Висновки. Підсумовуючи сказане вище, можна зробити висновок, що впровадження у навчальний процес сучасних IКТ у раціональному поєднанні з традиційними методами навчання математики $є$ потужним засобом підвищення якості освіти та ефективності навчального процесу, зокрема, при навчанні вищої та прикладної математики студентів технічних спеціальностей скороченого терміну підготовки. Анкетування та опитування студентів підтверджує, що вони вважають за найкраще саме таку модель навчання вищої математики.

\section{ЛІТЕРАТУРА}

1. Співаковський О.В. Теорія і практика використання інформаційних технологій у процесі підготовки студентів математичних спеціальностей / О.В.Співаковський. Херсон: Айлант, 2003. - 229c.

2. Триус Ю.В. Комп'ютерно-орієнтовані методичні системи навчання математики: [монографія] / Ю.В.Триус. - Черкаси: Брама-Україна, 2005. - 400с.

3. Морзе Н.В. Моделі ефективного використання інформаційно-комунікаційних та дистанційних технологій навчання у вищому навчальному закладі [Електронний ресурс] / Н.В.Морзе, О.Г.Глазунова // Інформаційні технології і засоби навчання. 2008. - № 2 (6). - Режим доступу: http://www.ime.edu-ua.net/em6/content/08mnvshi.htm.

4. Пахолко С.А. До побудови окремої робочої програми з вищої математики для студентів технічних спеціальностей скороченого терміну навчання / С.А.Пахолко // Дидактика математики: проблеми і дослідження: Міжнародний збірник наукових робіт. Донецьк: Фірма ТЕАН. - 2010. - Вип. 34. - С.27-33.

5. Collis B. Flexible learning in a digital world: experiences and expectations / Betty Collis, Jef Moonen. - London: Kogan Page Limited, 2001. - 231p. 
6. Heinze A. Reflections On The Use Of Blended Learning [Electronic resource] / Aleksej Heinze, Chris Procter // Education in a Changing Environment. 13th-14th September 2004. - University of Salford, Salford, Education Development Unit. - 2004. - 11 p. Mode of access : http://www.ece.salford.ac.uk/proceedings/papers/ah_04.rtf.

7. Tobin L. Get a degree be 'blended learning' [Electronic resource]/ Lucy Tobin // The Guardian. - 19 April 2011 - Mode of access :http://www.guardian.co.uk/education/ 2011/apr/19/distance-blended-learningdegrees.

8. Триус Ю.В. Комбіноване навчання як інноваційна освітня технологія / Ю.В.Триус, I.В.Герасименко // Теорія та методика електронного навчання: збірник наукових праць. - Кривий Ріг: Видавничий відділ НМетАУ. - 2012. - Випуск III. - С.299-308.

9. Сінько Ю.І. Особливості підготовки викладачів і студентів до використання інформаційних технологій навчання математики у вищих навчальних закладах / Ю.І.Сінько // Інформаційні технології в освіті. - 2012. - № 13. - С.176-183.

Надійшла до редколегії 06.06.2017.

УДК 378.016:004

DOI 10.31319/2519-2884.32.2018.185

КАРІМОВ І.К., к.ф.-м.н., доцент

Дніпровський державний технічний університет, м. Кам’янське

\section{ДЕЯКІ АСПЕКТИ МАТЕМАТИЧНОЇ ПІДГОТОВКИ БАКАЛАВРІВ 3 УПРАВЛІННЯ ТА АДМІНІСТРУВАННЯ}

Вступ. Математичній підготовці менеджерів і економістів традиційно приділяється велика увага, оскільки математичне моделювання $\epsilon$ основним методом розв'язання більшості задач, які зустрічаються в їх фаховій діяльності. Саме тому в програми підготовки, окрім класичних дисциплін „Вища математика” і „Теорія ймовірностей та математична статистика", в різні часи включались прикладні математичні дисципліни „Математичне програмування”, „Методи і моделі прогнозування”, „Дослідження операцій”, „Економіко-математичне моделювання”, „Оптимізаційні методи і моделі”, „Економетрика” тощо.

Методологічні питання математичної підготовки в вищих навчальних закладах досліджувалися в працях багатьох вітчизняних та зарубіжних науковців, які розглядали загальні принципи і підходи до проблеми [1-2]; уточнювали зміст підготовки майбутніх управлінців та економістів [3]; аналізували проблему в світлі компетентнісного підходу [4-5]; досліджували можливості використання новітніх інформаційних технологій [6-7]; обговорювали інші аспекти. Однак, час від часу виникає потреба в уточненні змісту та корегуванні акцентів підготовки з тих чи інших причин. Зокрема, до таких причин слід віднести зміни в організації навчального процесу, зумовлені прийняттям в 2014 році Закону України „Про вищу освіту” та введенням в 2015 році нового переліку галузей знань і спеціальностей, за якими здійснюється підготовка здобувачів вищої освіти.

Постановка задачі. Відповідно до Закону України „Про вищу освіту” підготовка бакалаврів ведеться за освітньо-професійними програмами, які розробляються вищими навчальними закладами. Формування освітньо-професійних програм супроводжується перерозподілом часу на вивчення тих чи інших дисциплін, певним зміщенням акцентів в напрямку підсилення професійної підготовки фахівців. Недостатня проробка питань уточнення змісту фундаментальних дисциплін (зокрема, математичних) при зменшенні відведеного для їх вивчення часу закономірно призводить до погіршення якості навчання. Аналіз вказаної проблеми, пошук можливих шляхів її вирішення і $€$ основною задачею даної роботи. 